\title{
THE LOGIKE LATREIA OF ROMANS 12: 1 AND ITS INTERPRETATION AMONG CHRISTIAN HUMANISTS
}

\author{
KIRK M. SUMMERS* \\ University of Illinois
}

\begin{abstract}
Scholars have debated whether the sentiment of sixteenth century reformers against material forms of worship derived from certain Neo-Platonic ideas proliferating in parts of Europe and disseminated by Erasmus or from strictly Scriptural principles that were initially formulated by the Old Testament prophets and given fuller expression in the New. This essay studies the reformers' interpretation of the phrase logike latreia at Romans 12:1, as well as other key passages. It concludes that, whether consciously or subconsciously, the reformers borrowed language concerning the material-spiritual dichotomy of worship, not directly from Neo-Platonists, but from a commonplace used by numerous Roman writers. Early Church Fathers had long ago turned the same commonplace against pagan rivals, but now the reformers were employing it against the Catholic Church itself.
\end{abstract}

KEY WORDS: worship, Romans 12:1, Erasmus, Calvin, Neo-Platonism

\section{Introduction: The Spiritual-Material Dichotomy}

One of the major features of the Reformation movement in the sixteenth century was the criticism of materialism in Catholic worship and a corresponding call for the spiritualization of piety. Scholars have long debated the antecedents of this anti-materialistic rhetoric among the reformers along with its corresponding focus on inner, spiritual worship. Two opposing views on the matter are set forth by Carlos Eire in his book, War against the Idols. The Reformation of Worship from Erasmus to Calvin, and by Philip Butin in his article, 'John Calvin's Humanist Image of Popular LateMedieval Piety and Its Contribution to Reformed Worship' (Eire 1986; Butin 1994), which presents itself as a critique of Eire's thesis, particularly as it pertains to John Calvin. In the matter of worship, Eire sees a continuity of 
Platonist dualism through the Florentine Neo-platonists to Erasmus and other humanists, which in turn became the inheritance of the reformers (1986: 53, n. 91). This dualism reinforced ideas Erasmus had already absorbed through the writings of the Devotio Moderna, such as Thomas à Kempis' De imitatione Christi, and the 'flesh-spirit' dichotomy found in the New Testament (Eire 1986: 32-33; Bainton 1969: 61). The reformers, in Eire's view, understood the word 'spiritual', as in 'spiritual worship' or 'to worship God in spirit', through the Neo-Platonist lens, that is, as a contrast with material worship. Worship, in this view, should be internal, an inner exercise, not an external one. Butin objects to Eire's reconstruction, arguing specifically that Calvin had the proper Pauline understanding of 'spiritual worship' as being that which involves the Holy Spirit as opposed to 'carnal worshi', or 'legal worship', that is, worship devised by human ingenuity to appease or even manipulate God (Butin 1994: 421-422).

The viewpoints of Eire and Butin represent only one volley in the centuries-old debate about the the source and extent of strong dualistic tendencies among the reformers. Christian Grosse has argued that our modern conception of these tendencies stems from eighteenth and nineteenth century historiography, with its exaggerated emphasis on the anticeremonialism of the Reformed movement (Grosse 2004). He suggests that modern scholars often overlook Protestant efforts to refashion ritual communication with the divine because they have too readily accepted this dualistic paradigm. He demonstrates in his own work that Reformed Genevans developed new rituals in regard to the Eucharist to replace the old ones. This observation requires us to rethink the patently anti-ceremonial and antimaterialistic statements of sixteenth-century theologians. If they do not betray a Neo-Platonic worldview that the reformers had unwittingly adopted, as they seem on the surface, from where do they derive?

First and foremost, they have their basis in the Scriptures, as we shall see. Butin is right to note the strong sentiment found in the reformers that medieval modes of worship are man-devised and not founded on clear principles laid down in both Testaments. And to be fair, Butin overstates his case against Eire in this matter. Eire, for example, duly notes two strands of thought in Zwingli concerning worship, one that distinguishes between 'rites of divine origin and humanly devised observances', and one that objects to external rites that direct 'the worshiper's attention to the material world'. Of Zwingli's 'theology of idolatry', Eire concludes: 'It was guided by the hermeneutic of transcendentalism he had picked up from Erasmus, but it was unrestrained by any kind of compromise with nonscriptural authority' (1986: 54). A similar parallelism of ideas, Eire observes, runs through the tract published at Basel in 1521, titled On the Old and the New God; there the anonymous author rails against both the 'idolatrous materialism' of the 
Catholic Church, which elevates the creature and the external over Scripture, as well as worship that follows human invention instead of God's commands (1986: 76).

What has not fully been appreciated in all of this, however, is the extent to which the reformers borrowed the language for the criticism of material worship from pagan writers who were engaged in a similar critique of their own pagan cult. Although the Scriptural foundation for the reformers' thinking is undeniable and even preeminent, it is the argument of this essay that the thorough grounding in Classical humanism that characterizes many of the sixteenth-century reformers also played a subtle role when they began to talk about what it means to worship God spiritually. In other words, the commonplace against external piety and non-spiritual worship from pagan antiquity impacted the reformers' rhetoric about medieval ceremonialism. The Church Fathers, it should be noted, had used the same commonplace of pagan intellectuals against their pagan contemporaries, turning the tables on them. Thus, in attempting to convince their Catholic rivals that they had merely substituted true and sanctioned rituals with man-made ones, the reformers took note of this early theological strategy. The result is that the reformers essentially accuse their Catholic counterparts of reviving paganism.

The criticisms at issue here make their appearance in a wide range of genres, from tracts to commentaries. To ground our own argument, we will concentrate on the reformers' interpretation of one particular passage, Romans 12:1, where we find the elusive and enigmatic phrase logike latreia, variously interpreted in a range from reasonable service to rational worship. The phrase is just ambiguous enough to allow us to observe some straining among the reformers to interpret it and to understand its application to public worship.

\section{A Classical Commonplace}

We begin with a brief survey of the commonplace on worship as it handled in ancient authors. For this we turn to a comment made by the great humanist scholar, Denys Lambin, who recognized that the pagan or philosophical criticism of external cult and the early Christian criticism of it shared the same underlying rationale. In his magisterial 1570 edition of Lucretius, commenting on the pericope of the De rerum natura that begins at 5.1198, where the Epicurean poet ennumerates what in his view piety does not entail - the slaughtering of four-footed animals, veiling the head, prostrating before idols, stringing up votive offerings-Lambin duly notes the parallel between this sentiment and one found among the Church Fathers. He offers the following remarks: 
Nam pietas nulla'st, etc. Lactantius cites his verse, together with the four that follow, in book 2 of his On the Origin of Error. Along the same lines to what Lucretius says here is what Arnobius says at 4[.30 of his Against the Pagans]: 'True worship is in the heart, and also a belief worthy of the gods. Neither does the bringing of blood and gore avail anything, nor if you believe things about them which, not only are far removed from their divine and excellent nature, but also add something of a stain and disgrace to their majesty and glory' (Lambin 1570: 502-503).

Lambin has stumbled on something significant here. The Church Fathers knew very well a tradition in ancient literature, both philosophical and popular, in which pagan ceremonialism was criticized for various reasons, and they borrowed those same arguments and turned them against both pagan and Jewish practices in favor of a more pure, thoughtful, inner worship (Young 1972: 278-281; Attridge 1978: 45-78; Daly 1978; Hanson 1980: 910-73, esp. 916-17; Ferguson 1980: 1151-1189; Bradbury 1995: 331-356; Stroumsa 2009; Ullucci 2011). We must stress, however, that, while Plato provided the initial impetus for these criticisms with his rather broad denunciation of materialism in worship (Laws 4.716D-F, 12.955E, 10.885B), which in turn saw some important reworkings in later Neoplatonist thought, reservations over external expressions of piety permeated mainstream philosophical and popular thought so thoroughly that it seemed only a proverbial piece of Greco-Roman wisdom.

This becomes evident in Erasmus' commentary of the Disticha Catonis 1.1, which touches on the dichotomy between spiritual and material worship (Si Deus est animus, nobis ut carmina dicunt, | Hic tibi praecipue sit pura mente colendus). For Erasmus, Plato's ideas form but one part of the collective wisdom of antiquity that treats this issue. He writes,

The common person used to think that God is pleased with victims of beasts and by material things, but since God is spirit, that is, mind, not body, and it is usual for like to take pleasure in its like, surely, above all else, he must be worshiped by you with purity of mind. But even today the average Christian worships God with certain material ceremonies, although the most pleasing worship is piety of the mind. For the Father desires worshipers who worship in spirit, since he himself is spirit. For no piety is more pleasing to the gods than if you imitate their lives: forbearance, gentleness, purity. Now these are spiritual things and God is spirit. As best you can, withdraw yourself from the body and approach him to the extent of your ability and offer up a most pleasing sacrifice. Pura mente: Commonly people approach the Holy with washed hands and feet. Instead, cleanse your mind. The uncleanness of the common person offends God, who sees those things which are in the mind, not in the body. Si Deus: The 'if' is not of one who is doubting, but is part of the logical argumentation. Ut carmina: Verg., Aen. 6 calls God spirit and mind. Praecipue: He adds this so you can understand that corporeal worship is not being condemned, but that spiritual worship is most pleasing to God (Erasmus 1646: 10-11). 
Erasmus here relies on a compilation of ideas from across the spectrum, including Plato ('like takes pleasure in like'), Lucretius ('victim of beasts', cited above), Cicero ('purity of mind', on which see below), and Vergil, who is explicitly quoted. Erasmus' thoughts on the matter are not so much a product of a specific philosophical allegiance as much as an appreciation for certain widely-held opinions emerging from the ancient world to which later reformers also had access.

The commonplace has a rich and varied history, manifesting itself in different authors in different ways. Here, before we examine specific passages (in addition to those of Lucretius, Vergil, and Cato, cited above) that most impacted the reformers, it should be noted more broadly that throughout Greco-Roman literature four strands or variations of the commonplace's argumentation are discernable. They can be reduced to the following four:

1. the gods are omnipotent and need nothing material from us

2. a hierarchy of ritual should correspond to the hierarchy of divinity

3. the gods value inner attitude over material worship

4. the gods are spiritual beings and therefore can only be accessed through our spiritual aspect.

All of these variations point to the overarching idea that worship in its highest and purest form is properly a mental activity, because God is immaterial and is therefore not impressed by the material. The value of this for condemning medieval ceremonialism was not lost on the reformers (even if they relied primarily on Scriptural support), just as it was not lost on the early Fathers who wanted to disparage ritual paganism and Judaism.

Although the germ of the idea contained in this topos can be found in Plato's Laws and traced through the Academic tradition, as mentioned above, it is in later passages of Roman literature where the topos is more fully developed that we find the language and rhetoric that most attracted the reformers. In particular, passages from Cicero, Persius, and Seneca prove most influential and so deserve some brief attention here. It will become clear, as we examine what the reformers had to say about worship, that these passages form an integral part of the story.

We turn our attention first to Cicero's De legibus 2.24-5, a work in which the Roman orator-intellectual attempts to imagine laws that are directly founded on universal Reason. In this particular passage, he downplays the value of outward rites for worship (the sprinkling of water, the passage of days) in comparison with the careful attention to mental purity. The mind as the superior to the body (animus corpori praestet) should be the focal point of our concern for a chaste approach to the gods. Purity begins within and 
moves outward, but never conversely. Even great expenditure and pompous display should be avoided during worship, he says, because they detract from the gods' main interest, namely, that the heart be upright. No more than a citizen should expect to influence a judge with status or wealth, but only with the goodness of character, so we all should aspire to stand before the gods with only the advocacy of our mind's piety.

Persius echoes Cicero's argument at the end of his satire about human prayers (Satire 2). After making the case that people often ask the gods openly and perfunctorily for spiritual benefits, a good mind, reputation, credibility (mens bona, fama, fides, 8), while in whispered tones and private situations asking for gaudy material items, he concludes with the familiar topos: Gold as an offertory gift has no value within the temple; the gods desire an offering of inward purity and goodness (compositum ius fasque animo sanctosque recessus / mentus et incoctum generoso pectus honesto, 73-4). Persius explicitly treats the problem as a misunderstanding of the gods' character, as if the gods fall to the same greedy lust for outward possessions as humans do. Humans mistakenly believe they can garner the favor and blessing of spiritual beings by making physical and material gestures. Instead, they would have more success by communicating with the gods spirit to spirit, mind to mind. Ovid echoes a similar sentiment in his Fasti (2.533-536) when talking about the worship of ancestral spirits:

There is a duty owed to tombs, to please paternal spirits, to bring small gifts to the pyres which have been built. The manes seek small things: They prefer piety to a costly gift. The Stygian depths do not possess greedy gods.

The manes do not reject outward expressions of worship explicitly here, but at the same time they do not associate extravagant display with pious devotion.

The commonplace finds its clearest expression in an epistle of Seneca written to Lucillius (Ep. 115.5):

Worship does not consist in the slaughtering of bulls with fat bodies nor in the hanging up of gold or silver, and not in pouring coins into the offering plate, but in a will that is pious and upright.

Just as Lucretius modifies piety from its traditional characterization, as Lambin noted, so Seneca endeavors to redefine true reverence for the gods by advancing first the negation of it followed by a positive correction. In both cases, piety or worship does not consist in the ritual acts themselvesslaughtering fat bulls and fulfilling vows with rich offerings-but in a state of mind. For Seneca, that desirable state of mind is holiness and uprightness (see Attridge 1978: 68-69). 


\section{Rational Worship}

We now turn our attention to Romans 12: 1 and the phrase logike latreia. The passage itself, in two versions that would have been known to Protestant readers in the latter half of the sixteenth century, one the Latin of Beza (1556), the other L. Tomson's English version of the Geneva Bible (1576) that was based on Beza's Latin, is as follows:

Adhortor igitur vos, fratres, per miserationes illas Dei, ut sistatis corpora vestra hostiam vivam, sanctam, placentem Deo, rationalem illum cultum vestrum (Beza 1556: 195 of the NT; Beza 1598: pt. 2, 82).

I beseech you therefore brethren, by the mercies of God, that yee give up your bodies a living sacrifice, holy, acceptable unto God, which is your reasonable serving of God (Tomson 1599: Romans, 67).

Beza's wording, rationalem illum cultum vestrum, which Tomson renders in English with your reasonable serving of God, reflects the phrase logike latreia in the Greek text. Tomson glosses the word reasonable with spiritual, following Beza's annotation, which associates the passage with 1 Peter 2: 5, especially the phrase pneumatikas thusias in Greek, or spirituales hostias in Latin. Modern English translations reveal a long history of debate as how properly and precisely to render the phrase. Several use reasonable, as the Geneva Bible did, following the Vulgate's rationabilem, which Calvin also used. The Jubilee Bible of 2000 chooses rational worship, which mirrors Beza's translation most closely, and many commentators agree. For example, Thomas R. Schreiner bases his interpretation on parallel usages in Greek philosophy and concludes that Paul intends the sacrifice to be 'rational and reasonable'. Nevertheless, he rejects the assumption that the logikos and pneumatikos of 1 Peter 2: 5 are precisely synonymous, or that the translation spiritual can by itself 'do justice to Paul's reshaping of cultic language' (Schreiner 1998: 645-46). Others, such as F. F. Bruce, prefer the translation spiritual, which was Beza's gloss. In regard to his choice, Bruce writes:

Your spiritual worship. NEB, 'The worship offered by mind and heart.' The noun is latreia, used already in 9: 4 of the 'worship' ordained for the Israelites. The adjective is logikos (from logos, 'word', 'reason'), which may mean either 'reasonable' (the service of obedient life is the only reasonable or logical response to the grace of God) or 'spiritual' (as in 1 Peter 2: 2, 'spiritual milk'). Here 'spiritual worship' is probably set in contrast with the externalities of Israel's temple cult. In the Testament of Levi (3:6) the angels are described as offering to the Lord a fragrant odor, a spiritual (logikos) and bloodless sacrifice (Bruce 1985²: 223). 
Elsewhere one can find logical (reproducing the Greek word more literally), true and proper, appropriate, or intelligent worship (or service), or more periphrastic constructions such as truly the way to worship Him or the aforementioned worship offered by mind and heart. These variant interpretations of the phrase logike latreia fall into two broad categories: one showing the influence of the dualistic commonplace drawn from pagan writers and the early Church Fathers, the other more attune to the critique of medieval ritual as being not based on the Word of God and not sanctioned by the Holy Spirit. The conflict or tension between the two is an inheritance of a mixed message on the matter emerging from the sixteenth century.

What will occupy us here is not so much the latter variant in sixteenthcentury Protestant interpretation, that is, the idea that medieval ritual was non-Biblical (or 'self-made religion', as we read in Colossians 2: 23), rather, the echoes of pagan anti-materialism in regard to cult. The latter forms an important aspect of the Protestants' condemnation of medieval modes of worship, perhaps even blinding them to their own ritual substitutes. While they understood that this phrase rational worship (as I will refer to it from now on for convenience sake) evoked the need for the guidance of the Holy Spirit, they also perceived in it an admonishment against a reliance on the kind of external ceremonialism that predominated throughout Jewish and pagan cult. Protestant theologians, in other words, were so intent on the undoing of medieval ceremonialism that they sometimes drew from their humanistic training and their knowledge of pagan authors for their language and rhetoric. These pagan critiques of ceremonialism relevant to their own time naturally did not include Spirit-led ritual acts. As we have seen, these pagan writers sought to redefine piety and what constitutes true worship based on the notion that God, as a spiritual being, is only honored through spiritual observances such as goodness of heart and mind. The material is relegated to an inferior position unworthy of the divine.

The Old Testament provided a degree of support for such an interpretation of rational worship: 1 Samuel 15: 22 ('to obey is better than sacrifice'); Psalm 50: 7-15 ('a sacrifice of thanksgiving'); Hosea 6: 6 ('loyalty and knowledge is better than sacrifice'); Amos 5: 21-24 ('justice and righteousness surpasses ceremony'); Malachi 1:10-11 ('incense and pure offerings'). The concept appears as well in extra-canonical literature: Ecclesiasticus 35: 13; Testament of Levi 3: 6 ('a rational and bloodless sacrifice'); Manual of Discipline 8-9; Philo, De somniis 2.183. But it is important to note that in all these proclamations, the prophets were never really calling for an end to the ritual worship already ordained by God (Old 1990: 230-246) in the same way that the reformers were calling for the abolishment of medieval ritual. They were criticizing the attitude that their fellow countrymen had while conducting the prescribed rituals. 
Several passages of the New Testament emphasize the role of the Spirit in worship (e.g., Philippians 3:3 and the aforementioned 1 Peter 2: 5), without definitively condemning all ritual. In Hebrews, we do indeed find a stronger criticism of external ritual, with phrases such as the 'sacrifice of praise and doing good' (Hebrews 13: 15-16) and 'better sacrifices' (Hebrews 9: 23), as if the author is advocating the replacement of old external ceremonies with superior, spiritual ones. At least one scholar has suggested that the author of Hebrews himself drew from the same philosophical and rhetorical tradition described in the present essay (Thompson 1979: 567-578).

\section{Dualism in Philip Melanchthon}

In his book War against Idols, Eire devotes some attention to the dispute between Luther and his colleague Andreas Bodenstein von Karlstadt at Wittenberg over Catholic worship (Eire 1986: 55-73). In the early days of the Reformation, beginning as early as 1518 , Karlstadt began to develop an anti-material theory of worship that gradually grew more extreme over time. He begins with an 'opposition to externalized worship' that was 'generally limited to the use of material props in worship' (Eire 1986: 56), and over time, in works such as On Holy Water, expressed strong reservations that they could serve in any way except as a diversion from real faith. In his 1522 pamphlet, On the Abolition of Images, he takes the position that images in the Church lead to idolatry and their presence violates the first commandment.

But the real conflict with Luther begins when Luther is taken away to Wartburg and Karlstadt is able to exert more influence at Wittenberg (Eire 1986: 63). This is when Karlstadt began to put his theory into practice in the form of iconoclasm. Furthermore, in On the Priesthood and Sacrifice of Christ, Karlstadt attacks the Mass and refutes the doctrine of the real presence. Eire shows that this radical view caused Luther, especially after 1522, to adopt the opposite point of view, both for political and ecclesiastical reasons. Basically, Luther was indifferent to the role of externals and images in the Church and was not willing to see it as a metaphysical debate, but a practical one of Church policy: The almost obsessive concern over the removing of the material in worship, in his view, diminished the importance of grace.

What is particularly interesting in Eire's description of Karlstadt's push toward iconoclasm in Luther's absence is the detail that his protégé Philip Melanchthon (1497-1560) to some extent cooperated with Karlstadt in this endeavor. A look at how Melanchthon himself handled Romans 12: 1 gives us insight into his thinking. Since his commentary on Romans evolved, it is in the much expanded 1540 edition that his viewpoint becomes clear. There Melanchthon begins his study of Romans 12 by making general observa- 
tions about good works, which he sees as the main thrust of the chapter. He makes a distinction between interior good works and exterior ones. Interior motus, as he calls them, motions or inclinations, including faith, love, contrition, patience, prayer, are not in non-Christians, even if they can have external civic discipline. Then, after more discussion about whether or not these ethical efforts have the potential to please God, Melanchthon turns to the problem of understanding the phrase rational worship. He writes,

\begin{abstract}
Melanchthon's theoretical stance is in its essence really no different than that of Luther, even if the language is less popularized: He insists that faith and other inner pious 'impulses' be primary in worship. Yet he does not exactly show an indifference to external ritual, either, as Luther did. Melanchthon contrasts spiritual or mental worship, which is his gloss for rational worship, with the ceremonialism of the Old Testament that was just a shadow of a more perfect, inner worship after the arrival of the Messiah. The structure of the sentence that begins, 'Paul excludes', creates a parallel or correspondence between 'animal sacrifices' and 'the traditions of monks', leaving the qualification provided by the quandocumque ('whenever') to apply to moral works specifically. And the ritual of the Mass as a ceremony meant to have efficacy and value as a 'work worked' is rejected out of hand since it does not concern itself with one's spiritual attitude. In the latter one can detect the influence of Cicero's passage from the De legibus: While external acts are not disallowed absolutely, only the upright heart impresses the divine.
\end{abstract}

\title{
Dualism in the Reformed Tradition
}

Melanchthon's comments on Romans 12:1 give a hint as to the tension running throughout the writings of the reformers in regard to the spiritualization of worship. Butin's objection to Eire's conclusions, however, concerns Calvin in particular, and so it is on the tradition that he represents that we will concentrate our study. We turn our attention first to Reformed theologian Wolfgang Musculus (1497-1563), professor at Bern, and his 1555 commentary on Romans. There, in his analysis of the first verse of chapter twelve, he raises the question 'how we ought to offer ourselves to God as a sacrifice' (Musculus 1555: 282-283). Some people, Musculus says, think it means that we should sacrifice 'the old man', but he rejects this view, because the old man is impure and therefore not a fitting sacrifice to a God who under the old covenant wanted unblemished animals. Believers sacrifice themselves to God through obedience, and by following in the footsteps of Christ. He contends that the word rational here evokes its counterpart irrational, which suggests the worship through the sacrificing of irrational animals, as in the Old Testament.

This is an important line of thinking that Theodore Beza (1519-1605) likewise follows in his interpretation of Romans 12:1, seeing there a 'tacit antithesis of the worship in which a person spiritually consecrates himself to 
God, and of the old worship, in which brutes, which the Greeks call irrational beings, and other things devoid of sense and reason, were being offered to God with the use of carnal ceremonies' (Beza 1598: pt. 2, 83; cf. Peter Martyr Vermigli [1499-1562] 1559: 1332-1333). The fact that Beza uses the phrase carnal ceremonies suggests that he has in mind, not so much Old Testament modes of worship, since those were sanctioned by Law, but the attempts of most cultures in antiquity to please God with external spectacles.

Musculus, for his part, observes that Paul wants to supplant the old mode of thinking about worship. He fears that 'simple-minded' Christians will feel uneasy that their religion does not contain the pomp and ceremony which people everywhere innately assume is proper for the worship of God and for that reason may slip back into ceremonialism. Christians, and Christians alone, are capable of a new kind of worship. He adds,

According to the apostle, this is the true worship of God, if someone offers himself wholly to God according to the example of Christ. The Catholic priests think that the worship of God consists in external ceremonies, in gold, silver, purple vestments, candles, and other trifles of this kind. If you take away these things, they will exclaim that the worship of God has been removed! You would end up enduring from them what the prophets once did from the Jews, and the apostles did from the Jews and the Gentiles (Musculus 1555: 282).

Musculus urges his readers to sacrifice through obedience, and no doubt he understands that this obedience is spirit-led worship, since the ability to obey is a function of the Holy Spirit in believers. Musculus is careful to use a passive mood when talking about believers' conformity to the example of Christ's self-sacrifice: 'exemplar hostiae Christi accedamus illique conformemur'. But his comments, echoing Lucretius and Seneca, nonetheless draw a sharp contrast between external ceremonialism and material worship, both of the ancient Jews and pagans, and of the current Catholic Church, between which he sees a parallel. So while the emphasis throughout is on the obedience and the offering up of oneself whole to God by taking up one's cross and following Christ, the spiritual-material, or internalexternal dichotomy finds clear expression at the same time, somewhat unexpectedly.

As noted already, Butin contends that for Calvin himself the dichotomy was not so much Platonic, spiritual vs. material, as spirit-led vs. carnal, the latter of which he understands as man-made modes of worship. This argument, in fact, is borne out by Calvin's interpretation of the phrase rational worship. In his 1540 commentary on Romans, Calvin believes that in this verse Paul is advocating obedience as the correct form of worship, and that when the apostle says reasonable service, as he understands the phrase, Paul is repudiating 'devised and invented forms of worship', which is an empty 
show of wisdom that attempts to go beyond the standard of God's Word (Calvin 1540: 335-336).

At the same time, in two other places where he is making the same point, Calvin turns to the aforementioned passage of Persius to bolster this point. In his 1554 commentary on Acts 17:24-25, for example, Calvin examines Paul's proclamation to the Athenians that God does not need the temples that mankind builds or the works of human hands. After establishing that by the latter phrase, works of human hands, we have a reference to outward ceremonies of worship, he goes on to associate it with the prophetic critiques of worship in the Old Testament, and with the philosophical critiques of Greco-Roman antiquity. The only difference he sees between the two is that the Jews were more likely to understand the ceremonies to be rudiments to assist in the spiritual worship of God, which is all God cares about. And so he writes about the Gentiles,

When they erected images, they offered incense, they set forth plays, and laid their cushions before the idols, they thought they had fulfilled the offices of godliness excellently well. Not only the philosophers, but also the poets, sometimes deride the folly of the common people, because they misplaced the worship of God in the pomp and beautiful display of ceremonies. That I may omit infinite testimonies, that of Persius is well known... (Calvin 1554: 53)

At this point, Calvin goes on to quote the relevant part of Persius' Satire 2 at length. He then notes that God endowed profane men with such insights so that they would be without excuse when they returned to the same ignorant worship that they criticize. This is part of a larger point that he wants to make, namely, that only the Word of God, and not philosophy, can lead one to the true worship of God. Even so, the emphasis of his complaint against false worship is on external observances as opposed to inward obedience and spirituality; he is, in essence, equating the Catholicism of his day with Roman paganism as a human-devised religion. Thus elsewhere, in a letter dating to 1542 written to a priest, Calvin deems the pomp and elaborate display of Roman Catholic worship to be 'more appropriate for pagans than for Christians' (Maag 2016: 53-55; cf. 116-124 and 136-138).

Calvin makes a similar appeal to Persius in his lectures on Haggai 2: 1115, where the prophet is drawing a lesson from the Mosaic Law about the power of the polluted to defile the clean by association (Calvin 1559: 588590). The Lord, he says, considers the relation between the people's sacrifices and their spirituality to be organic: their inner 'deadness' causes their external sacrifices to be reckoned polluted in the sight of the Lord. Calvin recognizes that in order to be obedient to Old Testament law, the Jews had to engage in certain sacrifices and rituals. The complaint of Haggai, however, also directs them to take into account the impurity of heart that accom- 
panies their worship. For Calvin, the application extends well beyond the Jewish people. People in general recklessly trifle with God like children do their puppets, he says: they offer sacrifices for show, with no substance behind them, attempting to manipulate God as with artificial playthings. This is a habit that even the pagans through natural knowledge and in the 'marrow of their bones' have practiced. He points to Persius' Satire 2.73-74, where, more than gold, the gods are said to love 'justice and right written on the soul, minds that are deeply pure, a heart imbued with nobleness'.

True holiness lies within, Calvin adds, and cannot be covered over by external expressions of piety. He additionally points to Ovid's Heroides 7.130, where Dido is made to say to Aeneas, 'An impious right hand does not well worship the heavenly gods.' As he did in his commentary on Acts, Calvin bemoans the irony that the poets and philosophers recognized the truth of this principle while trusting in the same rituals that they criticized, hoping ignorantly to win the favor of the gods. The lesson for those adhering to the papal religion is clear: they should heed Haggai's warning and give up any claims to partial righteousness through ceremony or outward works. A heart filled with pollution only further pollutes the external act. Now that ceremonies have come to an end, however, God requires from his people a heart regenerated by the Holy Spirit through faith and leading to the sacrifice of our whole selves in service and obedience to God. Papists should take note, he concludes, how the prophet ridicules his fellow countrymen for busying themselves in outward observances while neglecting that which God most demands, a heart marked by purity and sincerity.

Calvin has not rejected ceremonies out of hand here, but, as in the case of the Acts passage, he teaches that both Scriptures and natural knowledge call believers to inner piety and obedience far more than to external modes of worship. While he rejects human-devised ritual, he does not replace it with other external rituals, even if he sounds somewhat receptive to the possibility. It is clear that he believes that the kind of worship mandated by the Holy Spirit in the New Testament consists in obedience, purity of thought and action, and trust in God alone. It is of the mind and spirit rather than of the physical senses of touch, sight and smell. This is reflected in his criticism of the Catholic worship in the prefatory address of his Institutes (section 4), this time drawing on several passages of the Church Fathers, including Ambrose, who themselves look to pagan antiquity (Battles and McNeill 1960: 18-19). Calvin attacks the institutionalized church for thinking that 'God is not rightly worshiped unless everything swims with untoward splendor' and denounces their dependence on gold, silver, and other precious items to please God. The Church Fathers, he says, already advised you against this. 
Then at Institutes 2.2.24, while making the point that human knowledge cannot lead to correct worship, he alludes to Cicero's passage in the De legibus: 'They [sc. pagans] admit, of course, that God is not pleased with sacrifices unless sincerity of intention accompanies them.' Again he notes their tendency to accept the notion of spiritual worship then pervert it with 'false devisings'. Thus, we find Calvin censures a subtle tendency to oppose true and worthy expressions of piety, always described as internal or spiritual, with outward, ritualistic expressions for which no real substitute is offered. Obviously, he views the eucharistic celebrations and baptism to be divinely sanctioned, at least when performed in a certain way, but he is so keen to denigrate the external that he leaves little room for an alternative version of it in comparison with the spiritual. The rhetoric used to establish such a strong dichotomy is, in part, borrowed from pagan authors.

For another reading of Romans 12: 1, we can look to Heinrich Bullinger (1504-1575) and his commentary on the apostolic epistles (originally published in 1533; I have used the 1549 Zürich edition). Bullinger believes that Paul is trying to redefine worship for both Jews and pagans, both of whom think that God is served through the sacrificing of dead animals (Bullinger 1549: 96). Instead, Paul wants believers to offer themselves through purity and holiness of life (he does not fully follow through with the idea, as Daneau does [see below], that the Jews were sacrificing correctly according to the Old Covenant). He adds, 'Furthermore, it is a rational worship, pleasing to him, steadfast in faith and spirit, not with blood or gold or any external thing. For God is Spirit, and He wants to be worshiped in Spirit'.

Then he points the reader to Hebrews for the fuller presentation of the idea and adds that here 'all the invented and anathema sacrifices of human beings are rejected, while in their stead is commended purity and holiness of life'. This last sentence squares with what we saw in Calvin, with its emphasis on Paul's rejection of human-devised worship. But also to be highlighted here is the fact that in his interpretation of rational worship, Bullinger distinguishes between what is internal, faith and spirit, appropriate because God Himself is Spirit, and what is external, things that are material. There is the assumption that the mindset that Paul faced in regard to Jewish worship and the Fathers in regard to paganism is the same that current Christians face in regard to medieval ceremonialism. External rituals are invented rituals that need to give way to an inner attitude of holiness.

Other writers who can be placed within the Reformed tradition have similar interpretations. Theodore Beza, as observed above, interprets logike as spiritual, and rejects the Vulgate translation of rationabile obsequium (reasonable obedience), since that conveys the sense tempered by reason or moderate. This, Beza says, suggests a contrast with excessive and superstitious worship, or, one might say, human-devised worship (Beza 1598: part 2, 83). 
Instead, Paul is offering a new way of thinking about worship, with an inward orientation, a mental process, set against the old-covenant prescription of external ceremonialism. This inward orientation is not a mere escapism from the material world, however. Beza rejects this idea in his comments on 1 Peter 2: 2, where we find the phrase to logikon adolon gala (the only other place in the New Testament with our word logikos), and instead ties it to the Word, the hearing of which brings about regeneration in the hearts of believers (Beza 1598: part 2, 461; cf. Kingdon 2004: 41-60; Thayer 2012: 157-77; Manetsch 2012: 31-37). For Beza, then, receiving and obeying the Word of God is the true way to worship him: 'Here Peter contrasts infancy to the earlier, utterly corrupt life, and, considered in broader terms, commends the perpetual use of this milk, that is, of the true and sincere Gospel teaching' (Beza 1598: part 2, 461). As with the case of Calvin, a sharp dichotomy between external and internal predominates Beza's thought.

Peter Martyr Vermigli also connects rational worship to the proclamation of the Word in his commentary on this same passage (Vermigli 1559: 1333). Christians engage in sacrifice now, not by offering up brute animals, but by preaching, teaching, exhorting and admonishing their neighbors to obedience and imitation of Christ. It is as if, Vermigli says, Paul wanted to ease the minds of fresh converts, both Jewish and Gentile, who looked at their newly adopted religion as impoverished and meager, since it lacked the splendor and external apparatus that marked their previous worship. Piety does not need such external rites, the apostle wants to say, rather only a heart conformed to the Word of God.

There is some indication that Beza already found the essential dualistic thrust of the pagan commonplace appealing long before openly converting to the Protestant faith, which was more gradual than sudden (Manetsch 2006; 38-57). If this is true, that would mean that he became familiar with it through his humanistic training under the reformed-minded Melchior Wolmar. In the first edition of his poetry (1548), published nine months before his supposed sudden conversion, Beza includes a poem addressed to an unknown and perhaps fictitious priest named Marianus. The text and translation run as follows:

Augustas, Mariane, Deum venturus ad aras,

Nulla cremas magno thura Sabaea Iovi.

Nec capis externos cultum qui spargat odores,

Nec diti tractas aspera signa manu.

Gemmatae nunquam sudas sub pondere vestis,

Nec digitos onerat res peregrina tuos.

Sed placidam et nullo pollutam crimine mentem,

Atque sua notas a pietate manus, 
Caeteraque integros domini testantia mores,

Haec, inquam, magnis das, Mariane, deis.

Quod si rara solent merito pretiosa videri

Nemo dedit, nemo plus, Mariane, dabit.

As you approach the august altars of the gods, Marianus, you do not burn Arabian incense to great Jupiter,

nor do you worship by sprinkling foreign perfumes,

nor do you handle the carved icons with a rich hand.

You never sweat under the weight of a studded robe,

nor does anything exotic load down your fingers. Rather, you offer

to the gods, Marianus, a peaceful mind unstained by any evil deed,

and hands known for their piety, and other things

that testify to a person's pure character. For if we should view

rare things as precious, as is proper, then

no one has given more, Marianus, and no one ever will.

(Summers 2001: 236-237)

Here we can easily discern an indirect condemnation of medieval practice in the guise of positive praise and the vagueness of Classical allusions. There is no question that Beza draws much of the language from pagan authors. We observe the wording derived from Lucretius alone: approach the altars (venturus ad aras); sprinkling (spargat); peaceful mind (placidam mentem); piety (pietate). Additionally, one can detect the common complaints about the unneccessary costliness of the rites, the need for purity of character, the foreign extravagance in lieu of humble simplicity, all of which echo Cicero, Persius, and Seneca. Beza's Marianus exemplifies the ideal spiritual worshiper of the pagan thinkers to which Wolmar had exposed him.

One of Beza's colleagues at Geneva was theologian Lambert Daneau (c. 1535-c. 1590), perhaps best known for his books on hunting witches and for his efforts to square physics with Scriptures. In 1584 he published the second volume of his Christianae Isagoges, a presentation of Christian dogmatics that extended to five books (Daneau 1583-1588). Chapter 9 of the second book includes a section titled, De vero Dei cultu in genere, that relates to the question at hand. Daneau begins there by stating that God has shown us in the Scriptures how he desires to be worshiped, and that it is his will that he be worshiped logikoss, a path from which we should never stray lest we fall into countless errors. He then goes on to add that the cultus of God is duplex, which he summarizes as internal and external. The internal he defines as the 'earnest fear of God from faith, and conjoined with faith, which is exhibited to God by us in the conscience, and takes place in the heart'. For this he points to 1 Timothy 1: 5, John 4: 24, and 2 Corinthians 3: 17.

This worship, he continues, is most congruent to the nature of God, and in that sense is according to reason as Paul says at Romans 12: 1. God is spirit and so he wants what is spiritual from us. External cultus, however, is the 
testimony of the true piety of our spirit toward God, but it is manifest in different ways at different times in human history, and only valid if it is in the way God commanded it to be. This is true in both the Old and New Testaments. The Old obviously contains the story of Jewish cult, which earns approval because it is divinely sanctioned. Yet, unfortunately, Daneau fails to explain what properly constitutes external cultus for the New Testament Church, though he does remark that the best cultus is interior. Only the elect can truly exercise interior worship because it starts from the faith that they hold from the Word and promises of God, arising from a sense of the power and kindness of God, but not servile fear.

It is interesting that Daneau declines to delineate the external forms of worship available to the modern Church and instead focuses on a dichotomy of worship: cultus duplex. None of the passages that Daneau quotes lend strong support to this internal-external dichotomy of worship, rather, they make a distinction between spiritual and non-spiritual, which likely refers to Spirit-led worship in contrast to man-made ritual. His broad arguments indicate that he has an understanding of spiritual worship that harmonizes with reformed doctrine, but, as is the case with many of the reformers, at times in his language about worship and in his reading of the adjective logikos he drifts to a form of dualism of the material and the immaterial.

\section{Conclusion}

We began this essay by summarizing the opposing views of Phlip Butin and Carlos Eire on the source of the reformers' spiritualization of worship. Eire points to the influence of Erasmus after his contact with the Italian NeoPlatonists as an important contributing factor. Erasmus in part embraced their view that the spiritual aspect of man must transcend the material world in order to experience any real communion with the divine. This development in Erasmus' thought provides one context for the later reformers' disparagement of medieval modes of worship. Butin believes that Eire has unnecessarily gone looking for sources for this phenomenon and therefore drawn some incorrect conclusions. Calvin, he argues, drew his understanding of spiritual worship solely from the Scriptures. The reformer does not belittle material reality in favor of the spiritual in simple Platonic terms, but instead opposes proper, Spirit-led worship to improper, human-devised ritual. God has provided the blueprint for how to rightly communicate with him.

Christian Grosse's article on the doctrine of worship in the early Reformed movement sheds light on a problem in the historiography emanating from previous centuries. He argues that historians overemphasized the spiritual-material dichotomy in Calvin and others of the Reformed movement to such an extent that they created an inaccurate stereotype. In his 
view, we can and should find external ritualism in the thought and practice of the early reformers. They merely substituted new forms of approaching the divine as they rejected Papal religion. This raises the important question, however, as to why historians were so misled about the Reformed doctrine of worship in the first place. Why did they not readily see the interpretation that Butin describes? The problem lies in part with the reformers themselves. While espousing clearly the view that worship should be conformed to the Scriptures and thus spiritual or Spirit-led, they often turned to a pagan rhetorical commonplace that had its deep origins in Platonic thought. It was an idiom that they found most accessible in Roman writers and previously used by Church Fathers to criticize the ritual practices of contemporary Jews and the pagans themselves. This commonplace, which many of them learned in their early humanistic education or knew through the Fathers, seemed to them a powerful weapon in their battle against a Church that they believed had become superstitious and superficial.

We have attempted here to look for traces of this pagan commonplace by focusing our attention on the interpretation of Romans 12: 1 and the somewhat difficult phrase, logike latreia. This has led us naturally to the examination of other passages and writings as well. We can observe in these places that the reformers did indeed make use of the commonplace from ancient authors. Sometimes this is made explicitly clear, as when Calvin cites Persius in his commentary on Acts and his lectures on Haggai, or quotes Cicero in his Institutes, but more often than not, it manifests itself in the subtle and subconscious choice of words and expressions that recall the commonplace. There can be no question that the proverbial wisdom in regard to worship was deeply ingrained in the reformers' way of thinking and surfaces when polemicizing against medieval worship. Their failure to distinguish carefully between a philosophical anti-materialism that many pagan writers found pleasing and their own understanding of spiritual worship led to confusion about their doctrine. But appreciating better how their humanistic education impacted their rhetoric can go a long way toward clarifying why they expressed themselves as they did.

\section{Bibliography}

Attridge H (1978) The Philosophical Critique of Religion under the Early Empire. Aufstieg und Niedergang der römischen Welt II.16.1: 45-78.

Bainton RH (1969) Erasmus of Christendom. New York, NY: Charles Scribner's Sons.

Backus I (1980) The Reformed Roots of the English New Testament. The Influence of Theodore Beza on the English New Testament. Eugene, OR: Wipf and Stock Publishers. 
Beza T (1598) Iesu Christi Domini nostri Novum Testamentum sive Novum Foedus, cuius Graeco contextui respondent interpretationes duae, una vetus; altera, Theodori Bezae; eiusdem Th. Bezae annotationes. Geneva: E. Vignon.

Bradbury S (1995) Julian's Pagan Revival and the Decline of Blood Sacrifice. Phoenix 49(*): 331-356.

Bruce FF (1985²) Romans. An Introduction and Commentary. Downers Grove, IL: InterVarsity Press.

Bullinger H (1549) In omnes apostolicas epistolas, divi videlicet Pauli xiii et vii canonicas, commentarii. Zürich: Christoph Froschauer.

Butin PW (1994) John Calvin's Humanist Image of Popular Late-Medieval Piety and Its Contribution to Reformed Worship. Calvin Theological Journal 29(*): 419-31.

Calvin J (1540) Commentarii in Epistolam Pauli ad Romanos. Argentorati: Rihel.

Calvin J (1554) Commentariorum... in Acta Apostolorum, liber posterior. Geneva: Jean Crespin.

Calvin J (1559) Praelectiones in duodecim prophetas (quos vocant minores). Geneva: Jean Crispin.

Calvin J (1960) Institutiones Christianae Religiones. In Battles FL (trans) and McNeill JT (ed) Institutes of the Christian Religion, 2 volumes. Philadelphia, PA: Westminster Press.

Daneau L (1583-1588) Christianae Isagoges. Geneva: E. Vignon.

Daly RJ (1978) Christian Sacrifice. The Judeo-Christian Background before Origen. Washington, DC: Catholic University Press.

Eire CMN (1986) War against the Idols. The Reformation of Worship from Erasmus to Calvin. Cambridge: Cambridge University Press.

Grosse C (2004) 'En esprit et en vérité'? La part du rituel dans la culture religieuse réformée (Genève, $\mathrm{XVI}^{\mathrm{e}}$ siècle). In Selderhuis $\mathrm{HJ}$ (ed) Calvinus Praeceptor Ecclesiae. Papers of the International Congress on Calvin Research. Geneva: Droz, pp. 303-21.

Erasmus, D (1646) Dionisii Catonis Disticha de moribus ad filium; cum D. Erasmi Roterodami brevi expositione. Amsterdam: Joannes Janssonius.

Ferguson E (1980) Spiritual Sacrifice in Early Christianity and Its Environment. Aufstieg und Niedergang der römischen Welt II.23.2: 1151-1189.

George BG (1971) Sacrifice in the Old Testament. Its Theory and Practice. New York, NY: KTAV. Reprint of 1925 edition.

Hanson RPC (1980) Christian Attitude to Pagan Religions up to the Time of Constantine the Great. Aufstieg und Niedergang der römischen Welt II.23.2: 910-73.

Kingdon R (2004) Worship in Geneva and after the Reformation. In Maag $\mathrm{K}$ and Witvliet $\mathrm{J}$ (eds) Worship in Medieval and Early Modern Europe. South Bend, IN: University of Notre Dame Press, pp. 41-60. 
Lambin D (1570) T. Lucretii Cari De rerum natura... cum... commentariis illustrati. Paris: Jean Bienné.

Maag K (2016) Lifting Hearts to the Lord. Worship with John Calvin in SixteenthCentury Geneva. Grand Rapids, MI: Eerdmans.

Manetsch S (2013) Calvin's Company of Pastors. Oxford: Oxford University Press.

Manetsch S (2006) The Journey toward Geneva. Theodore Beza's Conversion, 1535-1548. In Foxgrover D (ed) Calvin, Beza, and Later Calvinism. Grand Rapids: CRC Product Services.

Melanchthon P (1861) Commentarii in Epistolam Pauli ad Romanos. In Nickel T (ed). Leipzig: Teubner.

Musculus W (1555) In Epistolam Apostoli Pauli ad Romanos commentarii. Basil: Johann Herwagen.

Old HO (1990) John Calvin and the Prophetic Criticism of Worship. In George T (ed) John Calvin and the Church. A Prism of Reform. Louisville, KY: Westminster John Knox Press.

Phillips J (1973) The Reformation of Images: Destruction of Art in England 15351660. Los Angeles, CA: University of California Press.

Schreiner TR (1998) Romans. Grand Rapids, MI: Baker.

Stroumsa G (2009) The End of Sacrifice. Religious Transformations in Late Antiquity. Chicago, IL: University of Chicago Press.

Summers K (2001) A View from the Palatine. The 'Iuvenilia' of Théodore de Bèze. Tempe, AZ: Arizona State University Press.

Thayer A (2012) Preaching and Worship. In Whitford D (ed) TET Clark Companion to Reformation Theology. London: Bloomsbury, pp. 157-77.

Thompson JW (1979) Hebrews 9 and Hellenistic Concepts of Sacrifice. JBL 98(4): $567-578$.

Tomson L (1576) The New Testament of our Lord Jesus Christ, translated out of Greek by Theod. Beza. Whereunto are adjoyned briefe Summeries of doctrine upon the Euangelistes and Actes of the Apostles, together with the methode of the Epistles of the Apostles, by the said Theod. Beza. And also short expositions on the phrases and hard places, taken out of the large annotations of foresayd Author and Joach. Camerarius, by P. Loseler Villerius. London: Christopher Barker.

Ullucci D (2011) The Christian Rejection of Animal Sacrifice. Oxford: Oxford University Press.

Vermigli PM (1559) In epistolam S. Pauli ad Romanos. Zürich: A. Gesner.

Young F (1972) The Idea of Sacrifice in Neoplatonic and Patristic Texts. Studia Patristica 11(*): 278-81. 